\title{
Diagnoses of Ovine Infection by the Serotype-4 Bluetongue Virus on Minas Gerais, Brazil
}

\author{
Pamela Aparecida Lima', Kiyoko Uemura Utiumi ${ }^{1}$, Karen Yumi Ribeiro Nakagaki', Daniel Arrais Biihrer', \\ Adriana Silva Albuquerque', Fernanda Rezende Souza', Ana Carolina Diniz Matos², Zélia Inês Portela Lobato², \\ David Driemeier ${ }^{3}$ Ana Paula Peconick', Mary Suzan Varaschin' \& Djeison Lutier Raymundo'
}

\begin{abstract}
Background: Bluetongue (BT) is a viral disease transmitted by hematophagous vectors of the genus Culicoides. In Brazil, the identification of antibodies against the virus has been held for over thirty years, however clinicopathological diagnosis of the disease are scarce. The first reported case occurred in the state of Paraná in 2001, confirmed by isolation and identification of serotype 12 of BTV. In the state of Rio Grande do Sul, in 2009, two outbreaks confirmed and was identified the serotype 12. Serotype 4 was isolated during an outbreak in the state of Rio de Janeiro in 2013. This study describes the Diagnoses of ovine infection by the serotype- 4 bluetongue virus in Minas Gerais, Brazil.

Case: In a farm in the Southern region of the state of Minas Gerais, a group of 28 male sheep, was sent for necropsy at the Setor de Patologia Veterinária of Universidade Federal de Lavras (SPV-UFLA). In a flock of 80 male sheep 28 died with clinical signs of respiratory distress, whereas other showed signs of anemia and hypoproteinemia, cough, sneezing, prostration, fever, mucopurulent nasal discharge, anemia and submandibular edema. At necropsy, the main changes observed were cranioventral pulmonary consolidation, hemorrhage at the base of the pulmonary artery and ulcerating lesions in the hard palate mucosa, rumen and reticulum. The histological changes consisted of bacterial bronchopneumonia, papillary necrosis associated with bacterial structures, multifocal vasculitis in the submucosa and thrombi in blood vessels of the serosa in the rumen and reticulum, hyaline and flocculate necrosis in esophageal muscle, skeletal and cardiac muscle fibers were also observed, associated with moderate mononuclear inflammatory infiltrate between fibers and around blood vessels. Discussion: The diagnosis of BT was confirmed by the identification of nucleic acids of the virus in blood samples and from tissues of animals from the herd by RT-PCR and by the detection of antibodies against Bluetongue virus with the agar gel immunodiffusion (AGID) test using serum samples from the remaining herd animals. Serotype 4 was identified in three of the samples inoculated into KC cells. The hemorrhage at the base of the pulmonary artery, one characteristic findings, was found in three of the necropsied sheep. The pulmonary lesions observed in the present study strongly suggest the occurrence of pneumonia caused by opportunistic bacteria, especially Mannheimia haemolytica, which is commonly associated with pneumonia in sheep infected with BTV. This work is the first in the state of Minas Gerais and the fourth in Brazil to report an outbreak of the disease with clinical signs. The economic impact of bluetongue results not only from the direct losses of animals to the disease, but also to the correlation among BTV infection and other problems including pneumonia, abortion and verminoses. In a study focused on the characteristics of ovine farming in Minas Gerais, farmers from the center-southwest reported that abortion and pneumonia were among their main problems. Thus, further epidemiological studies on BTV may improve the level of identification of infected herds and may help promote prophylactic measures. Necropsies and histopathology exams constitute crucial tools for diagnosis, because most cases present at a sub-clinical stage or in association with other, concomitant diseases.
\end{abstract}

Keywords: BTV 4, viral diseases, sheep, RT-PCR e IDGA.

${ }^{1}$ Departamento de Medicina Veterinária (DMV), Universidade Federal de Lavras (UFLA), Lavras, MG, Brazil. ${ }^{2}$ Departamento de Medicina Veterinária Preventiva, Universidade Federal de Minas Gerais (UFMG), Belo Horizonte, MG. ${ }^{3}$ Setor de Patologia Veterinária, Universidade Federal do Rio Grande do Sul (UFRGS), Porto Alegre, RS, Brazil. CORRESPONDENCE: D.L. Raymundo [djeison.raymundo@dmv.ufla.br - Tel.: +55 (35) 3829-1733]. Departamento de Medicina Veterinária - UFLA. Caixa Postal 3037. CEP 37.200-000 Lavras, MG, Brazil. 


\section{INTRODUCTION}

Bluetongue is a noncontagious viral disease transmitted by hematophagous insects of the genus Culicoides. The bluetongue virus (BTV) belongs to the genus Orbivirus of the Reoviridae family, and encompasses 26 known serotypes worldwide. Among ruminants, the ovine are the most susceptible to BTV, but factors such as breed, age, immunological status as well as environmental conditions and viral serotype affect disease severity. The lesions are characterized by pulmonary edema, hemorrhage, ulcerations of the digestive tract, muscle necrosis, hemorrhage in the subintimal layer of the pulmonary artery, and diffuse edema $[4,10]$. The worldwide distribution of BTV coincides with that of competent vectors and with adequate climatic conditions. The disease is considered endemic to tropical and subtropical areas in almost every continent [10]. Serological surveys indicated that BTV occurs across Brazil, with the highest prevalence of seropositive animals in the North and Southeastern regions and the lowest in the Southern region $[7,8]$. However clinicopathological diagnosis of the disease are scarce. The first reported case occurred in the state of Paraná in 2001, and identified the serotype 12 of BTV [5]. In the state of Rio Grande do Sul, in 2009, two outbreaks were confirmed to be serotype 12 of BTV [2]. Serotype 4 of BTV was isolated during an outbreak in 2013 on the state of Rio de Janeiro [3]. The aim of this study is report the occurrence of bluetongue disease in ovine from the state of Minas Gerais and the isolation of serotype 4 .

\section{CASE}

In a farm in the Southern region of the state of Minas Gerais, a group of 28 male Santa Ines sheep, from a herd of 80 animals, was sent for necropsy at the Setor de Patologia Veterinária of Universidade Federal de Lavras (SPV-UFLA). Soon after arriving at the property, some of the animals showed clinical signs of respiratory distress, whereas other showed signs of anemia and hypoproteinemia. Animals were treated with antimicrobial medication, and, as clinical conditions improved, treatment was interrupted. During the following two months, several animals became ill again with cough, sneezing, prostration, fever, mucopurulent nasal discharge, anemia and submandibular edema.

At necropsy the lesions more frequently occurred in the lungs; 18/28 sheep had cranioventral pulmonary consolidation (Figure 1A) and, one of them had food contents in the tracheal and bronchial lumen. A hemorrhagic area was observed at the base of the pulmonary artery on the heart of three animals (Figure 1B). There were moderate amounts of Haemonchus sp. specimens in the abomasum of 12 sheep. One animal displayed ulcerating lesions in the hard palate mucosa, rumen and reticulum (Figures $1 \mathrm{C} \& 1 \mathrm{D}$ ).

Tissue and organ samples were collected, fixed in $10 \%$ buffered formalin solution, and processed routinely for histopathology. Spleen, lung and lymph node samples, as well as blood were collected and kept at $-20^{\circ} \mathrm{C}$ until processing for the identification of the viral agent. Spleen, lung and lymph node fragments were macerated separately. Total RNA was extracted from $500 \mu \mathrm{L}$ of macerated tissue or from total blood by the phenol-chloroform method. The cDNA was synthesized using reverse transcriptase Superscript III (Invitrogen $\left.{ }^{\circledR}\right)^{1}$ with random primers. The cDNA was submitted to semi-nested RT-PCR for amplification of BTV segment 10, as described by Favero [6] in 2009. Products from semi-nested RT-PCR were separated by agarose gel electrophoresis (AGE) in $0.9 \%$ agarose gel with ethidium bromide and visualized under UV light. Samples with positive results in the semi-nested RT-PCR were inoculated in $\mathrm{KC}$ cells derived from $\mathrm{Cu}$ licoides sonorensis, provided by the Pirbright Institute, United Kingdom, for viral isolation. Isolated samples were then submitted to RT-PCR for amplification of BTV segment 2 and serotype identification. Serum samples from the remaining animals in the herd were collected and sent to the Animal Virology Laboratory of Minas Gerais Federal University for the identification of antibodies anti-BTV by agar gel immunodiffusion (AGID).

Histopathological exams revealed bacterial bronchopneumonia in 13 animals, characterized by hyperemia, edema, multifocal necrosis, and inflammatory neutrophilic infiltrates associated with basophilic granular structures that were compatible with bacterial colonies (Figure 2A). In four animals, we detected lesions in the esophageal muscle tissue, which corresponded to a moderate diffuse hyaline and flocculate necrosis associated with discrete inflammatory mononuclear infiltrates located between muscle fibers and around blood vessels (Figure 2B). Similar alterations of varying intensity were also found in the myocardium of three sheep and in the skeletal muscle of 10 animals. 

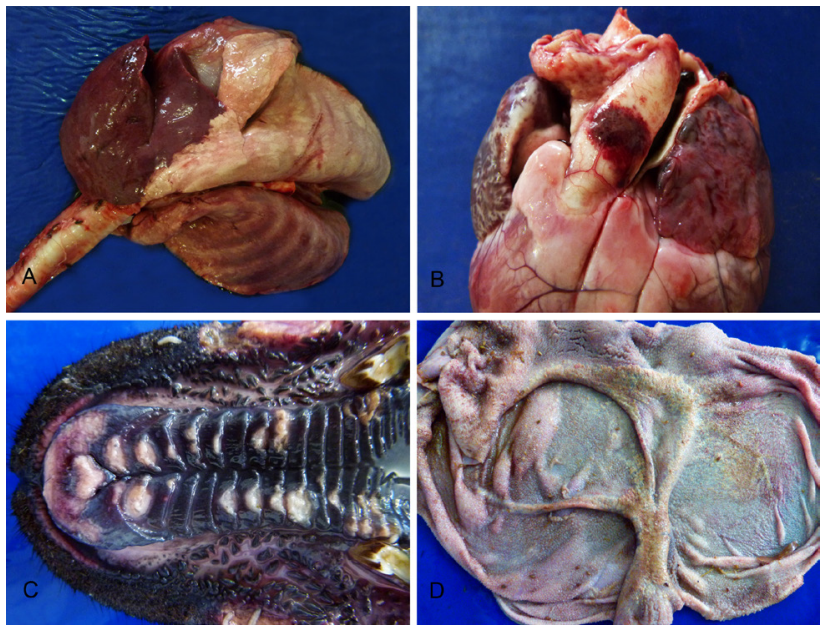

Figure 1. Natural infection of sheep by the bluetongue virus. (A)Lungs with cranioventral consolidation. (B)- Hemorrhage at the base of the pulmonary artery. (C)- Ulcerating lesions in the hard palate mucosa. (D)- Rumen with ulcerations and hemorrhage.

In the rumen and reticulum of one animal, we observed papillary necrosis associated with bacterial structures, multifocal vasculitis in the submucosa and thrombi in blood vessels of the serosa.

Spleen and lymph node samples from five necropsied sheep were positive for BTV by RT-PCR. The test detected viral nucleic acid in five of 21 blood samples analyzed. In the AGID test, nine of 14 serum samples were positive for BTV. Analyzed samples were infected with serotype 4 .

\section{DISCUSSION}

The necropsies and histopathological analyses of 28 dead sheep pointed to bluetongue disease, a diagnostic further confirmed by viral nucleic acid amplifi- cation by RT-PCR. Bluetongue lesions result from the invasion of endothelial cells by the virus, which induces hemorrhage, necrosis and tissue infarction. The release of vasoactive and inflammatory components further aggravates endothelial dysfunction increasing vascular permeability $[1,10,11]$. The hemorrhage at the base of the pulmonary artery, one characteristic findings [4], was found in three of the necropsied sheep. Degeneration and necrosis of smooth, skeletal and cardiac muscle are also defining characteristics of the disease [10] and could be found in nine animals. The presence of food matter in the trachea and bronchi of one animal, resulted from the dysphagia caused by muscle necrosis at the esophageal wall. The latter represents an occasional alteration in cases of bluetongue disease [2], which corroborates the diagnosis. The pulmonary lesions observed in the present study strongly suggest the occurrence of pneumonia caused by opportunistic bacteria, especially Mannheimia haemolytica, which is commonly associated with pneumonia in sheep infected with BTV [2,11].

In a majority of reported bluetongue outbreaks in ovine, the disease remained at a subclinical level. Nevertheless, some animals, with a secondary infection in relation to the herd, developed the clinical disease [2]. These results suggest that the virus remains silent in the herd, causing the clinical disease in few animals. Only one of the sheep in our study had severe bluetongue lesions including hemorrhage at the base of the pulmonary artery, necrosis of skeletal muscles, heart, esophagus and tongue, necrotic and hemorrhagic areas associated with vasculitis and thrombi in the mucosae
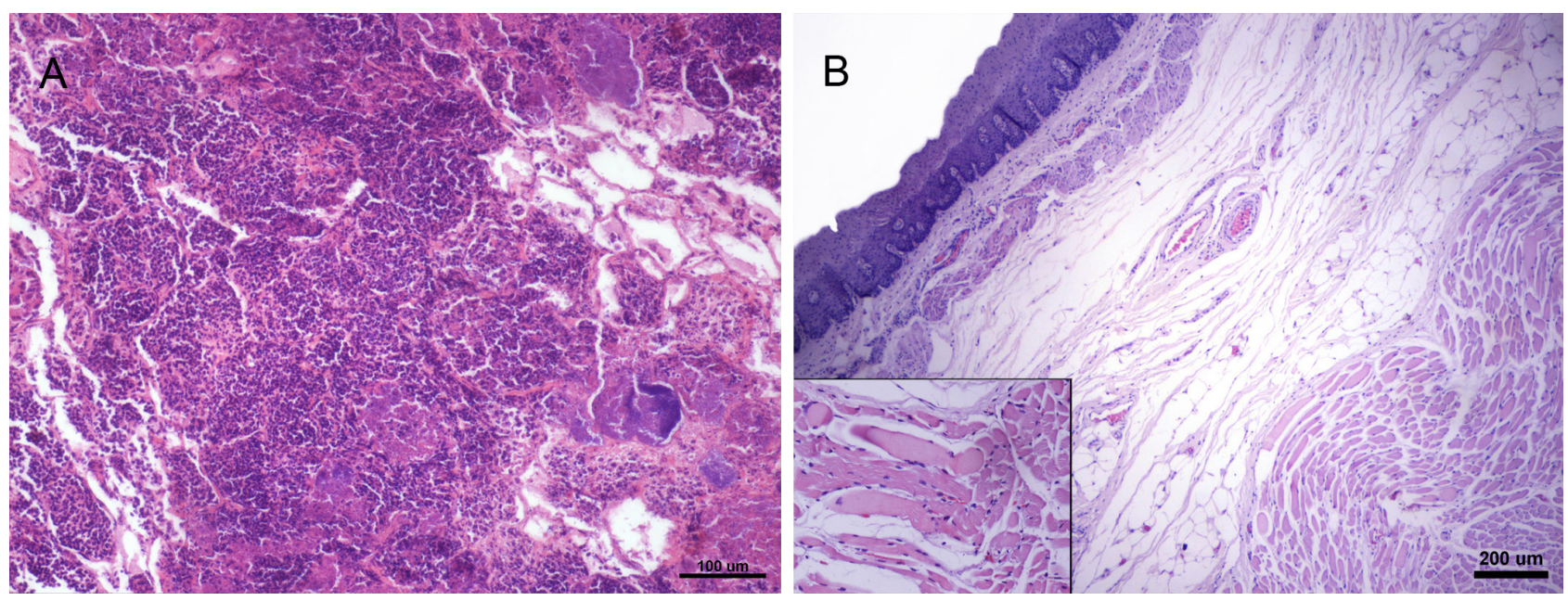

Figure2. Histopathological analysis of tissues from sheep infected with the bluetongue virus. (A)- Lungs. Multifocal necrosis with inflammatory neutrophilic infiltrates and intra-lesion bacterial colonies [HE. Obj. 20]. (B)- Esophageal striated muscle with diffuse hyaline necrosis of myofibers associated with discrete mononuclear infiltrates [HE. Obj. 20]. 
of the hard palate, rumen and reticulum. The other animals had subtler clinical signs and lesions, sometimes only observed under histological examination, and their cause of death was likely related to secondary factors.

The AGID used in the diagnostic represents the most commonly used technique of serological diagnostic in South America [9]. The positive result obtained from nine out of 14 samples indicates that the animals were previously infected with the virus, which circulates within the herd [10]. The BTV nucleic acid could be detected in samples of total blood from five sheep of 21 remaining ovine in the herd and from , lymph node and spleen of five necropsied animals. Serotype 4 was identified in three of the samples inoculated into KC cells.

In the Northeastern region of the state of Minas Gerais, a serum-epidemiological survey of BTV was conducted indicating that $58.6 \%$ of sheep in the region had been exposed to the virus [8]. However, this work is the first in the state and the fourth in Brazil to report an outbreak of the disease with clinical signs. The clinical-pathological alterations we describe here are similar to those observed in two other outbreaks in the state of Rio Grande do Sul [2], where the diagnostic was also confirmed by RT-PCR.
The economic impact of bluetongue results not only from the direct losses of animals to the disease, but also to the correlation among BTV infection and other problems including pneumonia, abortion and verminoses [1]. Thus, further epidemiological studies on BTV may improve the level of identification of infected herds and may help promote prophylactic measures. Necropsies and histopathology exams constitute crucial tools for diagnosis, because most cases present at a sub-clinical stage or in association with other, concomitant diseases.

\section{MANUFACTURER \\ ${ }^{1}$ Thermo Fisher Scientific. Waltham, MA, USA.}

\begin{abstract}
Acknowledgements. Flademir Wouters, of Veterinary Pathology Sector, Department of Veterinary Medicine, Federal University of Lavras, for assistance in correcting and composition of images. To Coordenação de Aperfeiçoamento de Pessoal e Nivel Superior (CAPES) for the the master's scholarships, to Conselho Nacional de Desenvolvimento Científico e Tecnológico (CNPq) for the scientific initiation scholarship, and to Fundação de Amparo à Pesquisa no Estado de Minas Gerais (FAPEMIG) for the scientific initiation scholarship and for the financial support to the project.
\end{abstract}

Declaration of interest. The autors report no conflicts of interest. The autors alone are responsible for the contentand writing of the paper.

\section{REFERENCES}

1 Alfieri A.A., Alfieri A.F., Takiuchi E. \& Lobato Z.I.P. 2007. Reoviridae. In: Flores E.F. (Ed). Virologia Veterinária. Santa Maria: UFSM, pp.773-807.

2 Antoniassi N.A.B., Pavarini S.P., Ribeiro L.A.O., Silva M.S., Flores E.F. \& Driemeier D. 2010. Alterações clínicas e patológicas em ovinos infectados naturalmente pelo vírus da língua azul no Rio Grande do Sul. Pesquisa Veterinária Brasileira. 30(12): 1010-1016.

3 Balaro M.F.A., Lima M.S., Del Fava C., De Oliveira G.R., Pituco E.M. \& Brandão F.Z. 2014. Outbreak of Bluetongue virus serotype 4 in dairy sheep in Rio de Janeiro, Brazil. Journal of Veterinary Diagnostic Investigation. 26(4): 567-570.

4 Brown C.C., Baker D.C. \& Barker I.K. 2007. Alimentary system. In: Maxie M.G. (Ed). Jubb, Kennedy and Palmer's Pathology of Domestic Animals. 5th edn. v.2. Philadelphia: Saunders Elsevier, pp.1-297.

5 Clavijo A., Sepulveda L., Riva J., Pessoa-Silva M., Tailor-Ruthes A. \& Lopez J.W. 2002. Isolation of Bluetongue Virus serotype 12 from an outbreak of the disease in South America. Veterinary Record. 151(10): 301-302.

6 Favero C.M. 2009. Padronização e aplicação de técnicas de diagnóstico para o vírus da língua azul e da doença hemorrágica epizootica dos cervídeos. 87f. Belo Horizonte, MG. Dissertação (Mestrado em Medicina Veterinária) - Programa de Pós-graduação em Medicina Veterinária, Universidade Federal de Minas Gerais.

7 Groocock C.M. \& Campbell C.H. 1982. Isolation of an exotic serotype of bluetongue virus from imported cattle in quarantine. Canadian Journal of Comparative Medicine. 46(2): 160-164.

8 Laender J.O. 2002. Língua azul em rebanhos de ovinos e caprinos em três mesorregiões de Minas Gerais: análise de evidência e sorológica e identificação de Culicoides sp. 92f. Belo Horizonte, MG. Dissertação (Mestrado em Medicina Veterinária) - Programa de Pós-graduação em Medicina Veterinária, Universidade Federal de Minas Gerais.

9 Lager I.A. 2004. Bluetongue virus in South America: overview of viruses, vectors, surveillance and unique features. Veterinaria Italiana. 40(3): 89-93. 
P.A. Lima, K.U.Utiumu, K.Y.R. Nakagaki, et al. 2016. Diagnoses of Ovine Infection by the Serotype-4 Bluetongue Virus on Minas Gerais, Brazil. Acta Scientiae Veterinariae. 44(Suppl 1): 143.

10 Maclachlan N.J., Drew C.P., Darpel K.E. \& Worwa G. 2009. The pathology and pathogenesis of bluetongue. Journal of Comparative Pathology. 141(1): 1-16.

11 Verwoerd D.W. \& Erasmus B.J. 2004. Bluetongue. In: Coetzer J.A.W. \& Tustin R.C. (Eds). Infectious Disease of Livestock. 2nd edn. v.2. Cape Town: Oxford University Press, pp.1201-1220. 